\title{
Understanding how customers engage with social tourism websites
}

Social tourism websites

\author{
Rafael Bravo, Sara Catalán and José M. Pina \\ Department of Marketing Management and Market Research, Faculty of \\ Economics and Business, Universidad de Zaragoza, Zaragoza, Spain
}

\begin{abstract}
Purpose - This paper aims to analyse the effect of technology acceptance variables on customer attitude and customer engagement behaviours (CEB) with social tourism websites (STWs).

Design/methodology/approach - An empirical study was carried out with 346 customers. A model was developed to analyse the relationships between CEB and their determinants. Partial least squares - structural equation modelling was used to test the model.

Findings - Customers' perceptions of enjoyment, ease of use, usefulness and trustworthiness positively influence their attitude towards STWs and their subsequent engagement behaviours [purchases, word of mouth (WOM) and referrals].

Originality/value - This study develops and empirically tests a model that analyses the impact of technology acceptance model variables on CEB, both transactional (customer purchases) and nontransactional (customer WOM, referrals and feedback), in the context of STWs.
\end{abstract}

Keywords Referrals, Tourism, WOM, Purchase, Customer engagement behaviours,

Social tourism website

Paper type Research paper

摘要

研究目的 - 本论文分析研究科技urism websitehaviours pur

研究设计/方法/途径 - 研究样本为研究科技urism websitehaviours purchasesLS-SEM分析验证假设模 型。

研究结果 - 研究结果表明, 顾客愉快感知、易使用、有用性、以及可信任度等变量对顾客社交旅游 网站的态度及后续参与行为 (购买、 $\mathrm{sOM}$ 、推荐) 有着积极影响。

研究原创性/价值 - 本论文开发并验证分析了科技接受模型变量对顾客参与行为的影响,包括交易性 （顾客购买）以及非交易性（顾客（OM、推荐、反馈）, 以社交旅游网站为背景。

关键词 顾客参与行为、社交旅游网站、购买、WOM、推荐、旅游

\section{文章类型：研究型论文}

\section{Introduction}

Social media, information sharing and user-generated content have significantly transformed the tourism and hospitality industry (Cai et al., 2019; Oliveira and Casais, 2019). A consequence has been the development of social tourism websites (STWs), tourismspecific social media sites that allow customers to share their travel experiences online

This study was supported by the Government of Spain and the European Regional Development Fund (project ECO2017-82103-P) and by the Government of Aragón (GENERES Group S-54_20R) cofinanced by FEDER 2014-2020 "Building Europe from Aragón”.
Received 26 February 2019 Revised 11 July 2019 13 December 2019 7 April 2020 29 June 2020 21 September 2020 Accepted 7 October 2020 
(Zhang et al., 2017). With dozens of STWs (Booking.com, TripAdvisor.com, etc.) competing in the market to attract users, questions are raised as to which specific features of the sites make them engaging for users and how this engagement provides value for the sites (Harrigan et al., 2017). Thus, they have attracted the interest of academics as platforms on which to study customer engagement behaviours (CEB) (Diffley and McCole, 2019).

Prior research on STW-related CEB has focussed primarily on purchasing behaviour, through the analysis of online bookings (Sparks and Browning, 2011; Casaló et al., 2015; Tsao et al., 2015; Chan et al., 2017). However, research on customer engagement (CE) has argued that focussing merely on purchasing behaviour underestimates customers (Kumar et al., 2010). In addition to transactional behaviours, such as purchases, non-transactional behaviours are becoming more important (Verhoef et al., 2010; Itani et al., 2020). In particular, the theory of customer engagement value developed by Kumar et al. (2010) identified three types of non-transactional interactions through which customers indirectly add value to firms. These are customer influence, customer referrals and customer knowledge (Pansari and Kumar, 2017).

STWs provide platforms for customers to engage, for the most part, with hotels and restaurants. This is reflected in the amount of research focussed on customers' recommendations and word of mouth (WOM) about specific hotels and restaurants (Xie et al., 2016; Zhang et al., 2017), hotel referrals (Slivar and Bayer, 2017; Itani et al., 2020) and customer feedback provided to hotels, mostly in the form of complaints (Hu et al., 2019). However, few empirical studies have analysed CEB with the STWs themselves. In particular, few empirical studies have analysed customer influence, or WOM, transmitted about STWs, and to the best of our knowledge, no previous study has analysed customer referrals and customer knowledge, or feedback, about the websites. To address this gap, this study proposes and tests a model to explain CEB with STWs and their determinants.

\section{Literature review}

\subsection{Customer engagement behaviours with social tourism websites}

In the past years, STWs have become especially critical in the information search phase (Diffley and McCole, 2019), as before booking individuals can learn about previous customers' experiences shared through online reviews (Zhang et al., 2017). Thus, many studies have addressed the role of online comments in customers' decision-making (Moro and Rita, 2018). Similarly, other works have focussed on those characteristics of STWs (aesthetics, website quality and ease of use) that might foster specific attitudes and behaviours, such as satisfaction and trust (Filieri et al., 2015; Chen et al., 2019). Previous research has also analysed the strategies adopted by companies in STWs, showing their impact on hotel ratings, eWOM and customer value (Xie et al., 2016; Diffley and McCole, 2019).

Most of the studies in the tourism literature have analysed CEB towards hotel brands facilitated by social media platforms. However, comparatively few have analysed CEB with the STWs. Among these works, some have focussed on the development of scales to measure CEB in these websites (Harrigan et al., 2017; Mkumbo et al., 2020) and the different ways customers participate on the social platforms (bookings, content creation and search; Chan et al., 2017; Lalicic and Weismayer, 2018), whereas others have examined intention to recommend these platforms or provide feedback (Filieri et al., 2015; Godinho-Bilro et al., 2018; Samala et al., 2019). Table 1 provides an overview of these works.

Regarding the drivers of CEB, Casaló et al.(2010) showed that factors included in technology acceptance models (TAM), such as perceived ease of use and usefulness, improve customers' attitudes, which leads to higher intention to participate in STWs and higher purchase intentions towards their featured products and services. These authors also found that these 


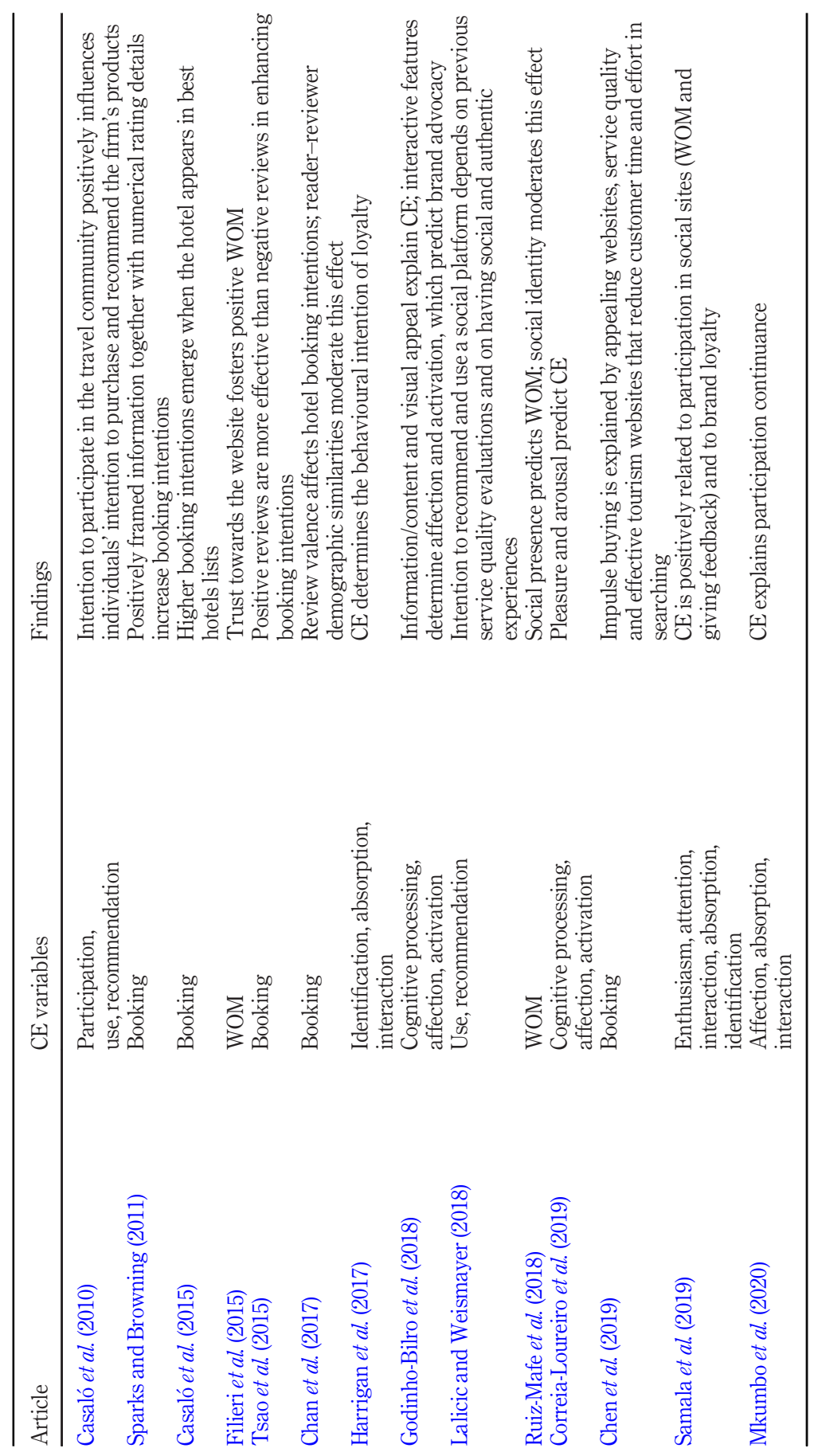

Social tourism websites

Table 1. CE with STWs 
factors predict customer intention to recommend STWs to others by creating more positive attitudes towards the sites. Similarly, some works have shown that other website-related factors, such as information content and visual appeal and customers' perceptions of trust, are pivotal for predicting customers' intention to participate on, and recommend, the site (RuizMafe et al., 2018; Godinho-Bilro et al., 2018; Correia-Loureiro et al., 2019).

\subsection{Hypotheses development}

The TAM, which has been widely used to analyse users' attitudes and behavioural intentions in tourism (Cai et al., 2019; Pourfakhimi et al., 2019), proposes that attitude towards new technologies is contingent on their perceived ease of use and usefulness (Davis, 1989). In particular, the TAM suggests that technologies that are easy to use are perceived as more useful (Davis, 1993; Venkatesh, 2000; Ayeh et al., 2013), and both factors promote a more favourable attitude towards the use of technologies (Davis, 1993). Perceptions of ease of use and usefulness positively influence individuals' attitudes towards the use of tourism platforms for travel planning (Di Pietro et al., 2012; Ayeh et al., 2013) and towards participation in travel communities (Casaló et al., 2011). Moreover, usefulness affects individuals' attitudes towards the advice provided by previous reviewers (Casaló et al., 2011). Hence, the following hypotheses are proposed:

H1. Perceived ease of use has a positive effect on customer attitude.

H2. Perceived usefulness has a positive effect on customer attitude.

H3. Perceived ease of use has a positive effect on perceived usefulness.

Davis et al.(1992) found that enjoyment is also important in motivating the use of information technology. If the use of the technology provides enjoyable experiences, individuals will be more likely to develop favourable feelings towards the technology (Di Pietro et al., 2012). Perceived enjoyment has been found to influence customer attitude towards social networks (Di Pietro et al., 2012; Hussein and Hassan, 2017), blogging platforms (Hsu and Lin, 2008) and tourism social media (Ayeh et al., 2013). In addition to its impact on customers' attitudes, perceived enjoyment positively influences perceptions of ease of use (Venkatesh, 2000); in other words, customers who enjoy STWs tend to find them easy to use (Ayeh et al., 2013). Therefore:

H4. Perceived enjoyment has a positive effect on customer attitude.

H5. Perceived enjoyment has a positive effect on perceived ease of use.

The success of any social media may be highly dependent on the trustworthiness of the information contained on that media (Hussein and Hassan, 2017). In tourism, some studies have shown that users' comments influence other consumers' travel planning (Ayeh et al., 2013; Kim et al., 2018). Thus, users will assess STWs positively if the comments posted on them are reliable (Casaló et al., 2011; Ayeh et al., 2013). In addition, if customers perceive that the information provided in STWs is trustworthy, they will also perceive that they are useful for decision-making (Casaló et al., 2011; Ayeh et al., 2013). Thus:

H6. Perceived trustworthiness has a positive effect on customer attitude.

H7. Perceived trustworthiness has a positive effect on perceived usefulness.

$\mathrm{CE}$ has recently gained attention from academic researchers, especially in services (Kumar et al., 2019) and social media settings (Carlson et al., 2019; Hinson et al., 2019). As the CE 
literature is still in an emergent stage, the operationalisation of the construct is still evolving. Although researchers agree that CE is multidimensional (Hollebeek et al., 2014; Kumar and Pansari, 2016), its conceptualisation varies. In her seminal paper, Hollebeek (2011, p. 555) defined it as "the level of a customer's cognitive, emotional and behavioural investment in specific brand interactions". This conceptualisation of $\mathrm{CE}$, which includes cognitive, emotional and behavioural components, is one of the most commonly accepted (Hollebeek et al., 2014; Hinson et al., 2019). Subsequent conceptualisations of CE have suggested that its dimensions are: identification, interaction, absorption, enthusiasm, affection and attention (Harrigan et al., 2017; Samala et al., 2019; Mkumbo et al., 2020). In an alternative approach, other researchers have posited that the CE concept should be limited to the customer's behavioural manifestations (Pansari and Kumar, 2017), and that cognitive and emotional aspects are its drivers. In this line, Kumar et al. (2010) defined CE as active interactions of a customer with a firm, with prospects and with other customers, whether they are transactional or non-transactional in nature (p. 297). Transactional interactions include customer purchases, whereas non-transactional interactions include customer influence, customer referrals and customer knowledge (Pansari and Kumar, 2017). This perspective, which has received increased recognition in recent research (Pansari and Kumar, 2017; Carlson et al., 2019; Itani et al., 2020), is especially suitable for examining the CEB that create value for companies.

Customer purchases are transactional interactions that have a direct effect on firms (Kumar and Pansari, 2016). In STWs, each time a customer makes a reservation the site earns a commission from the hotel or restaurant. In addition to purchases, customers engage with firms through non-transactional interactions that indirectly contribute to their sales results, as in the case of customer influence behaviour (Pansari and Kumar, 2017). Customer influence describes the impact customers make when they voluntarily generate WOM about firms (Kumar et al., 2010). Customer influence exercised through WOM has been reported as a very effective persuasion channel that can contribute to companies' reputations (Itani et al., 2020) and as a cost-effective means to market tourism and hospitality products/services (Cai et al., 2019). In addition to organic WOM, companies also benefit from customer referrals, firm-initiated, incentivised programmes that reward existing customers for bringing new customers (Pansari and Kumar, 2017). Customer referrals indirectly contribute to company performance, as they attract new customers who would not be attracted through traditional marketing channels (Kumar et al., 2010). Moreover, customer referrals are associated with higher margins and are more cost-effective than other marketing activities, such as advertising (Itani et al., 2020). Finally, customer knowledge is feedback provided to firms by customers based on their personal knowledge and experiences with firms (Itani et al., 2020). This feedback can help firms make their processes more efficient and their offerings more attractive to customers (Kumar et al., 2010). It is also useful in the generation of ideas for innovations and new products (Pansari and Kumar, 2017).

Based on the theory of reasoned action and the hierarchy of effects (Lavidge and Steiner, 1961; Fishbein and Ajzen, 1975), which provide support for the connection between customer attitude and behavioural intentions, it is expected that STW users who have positive attitudes towards them will engage with them. Hence:

H8. Customer attitude has a positive effect on customer engagement.

Figure 1 shows the proposed model.

\section{Methodology}

Data were gathered through a personal survey aimed at STW users. The fieldwork was carried out during May 2018 by a market research company. The data were collected 
through non-probabilistic quota sampling with age quotas based on the respondents' year of birth (total range: 1965-2000). The necessary condition to participate in the study was to have booked a hotel through a social tourism website in the previous 12 months. The respondents were randomly approached offline, and they had to indicate which STW they had used most recently; this constituted the basis for responding to the rest of the questionnaire. The sample was of 350 individuals, with 346 valid responses. The final sample consisted of 212 women and 134 men. Regarding age, 115 individuals were born between 1965 and 1979, 117 between 1980 and 1995 and 144 between 1996 and 2000.

The questionnaire items were measured on 10-point Likert-type scales. The composition of the scales and the references to prior works are shown in Table 2. Information about means and standard deviations are also included. To avoid common method bias, two statistical procedures were used. A non-related question was included in the questionnaire, and it was verified that it was not correlated to the scales. Similarly, a full collinearity test based on variance inflation factors (VIFs) was implemented. As the estimations showed that the VIF values were lower than 3.3, there is no evidence to suggest the presence of common method bias (Kock, 2015).

\section{Results}

Partial least squares (PLS) with SmartPLS 3.0 (Ringle et al., 2015) was used to test the model. PLS is more suitable than other structural equation modelling methods when the study is focussed on prediction and theory development (Reinartz et al., 2009) and when the model includes second-order constructs (Hair et al., 2011).

The model was estimated in a two-stage approach (Ringle et al., 2015). First, the reliability and validity of the research constructs were assessed (Table 2). All standardised factor loadings are above 0.7 and statistically significant at 0.01 , which indicates that individual item reliability is adequate. Moreover, all constructs were internally consistent as their composite reliabilities were greater than 0.7 (Nunnally and Bernstein, 1994). The constructs also meet the convergent validity criteria, as the average variance extracted (AVE) values are above 0.5 (Fornell and Larcker, 1981). Finally, discriminant validity is also supported. In all cases, the square root of the AVE for any two constructs is greater than the inter-construct correlations (Fornell and Larcker, 1981) (Table 3).

After evaluating the measurement of the first-order constructs, we included the latent scores of the purchases, WOM, referrals and feedback as indicators of CEB and re-estimated the model. We evaluated the model by analysing the significance of the variables. Customer feedback was removed from the construct, as it showed a non-significant weight and a low loading, and the model was re-estimated (Table 4). Collinearity was assessed based on the VIF values. The VIF values range from 1.28 to 2.68, all lower than 5, which suggests that multicollinearity is not a threat in this study (Hair et al., 2011).

Figure 1.

Proposed model

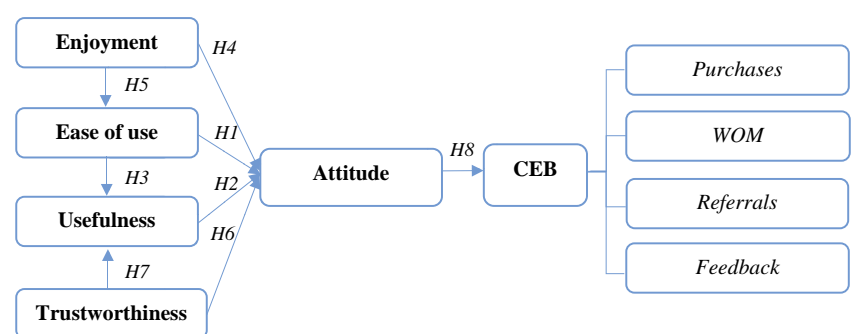




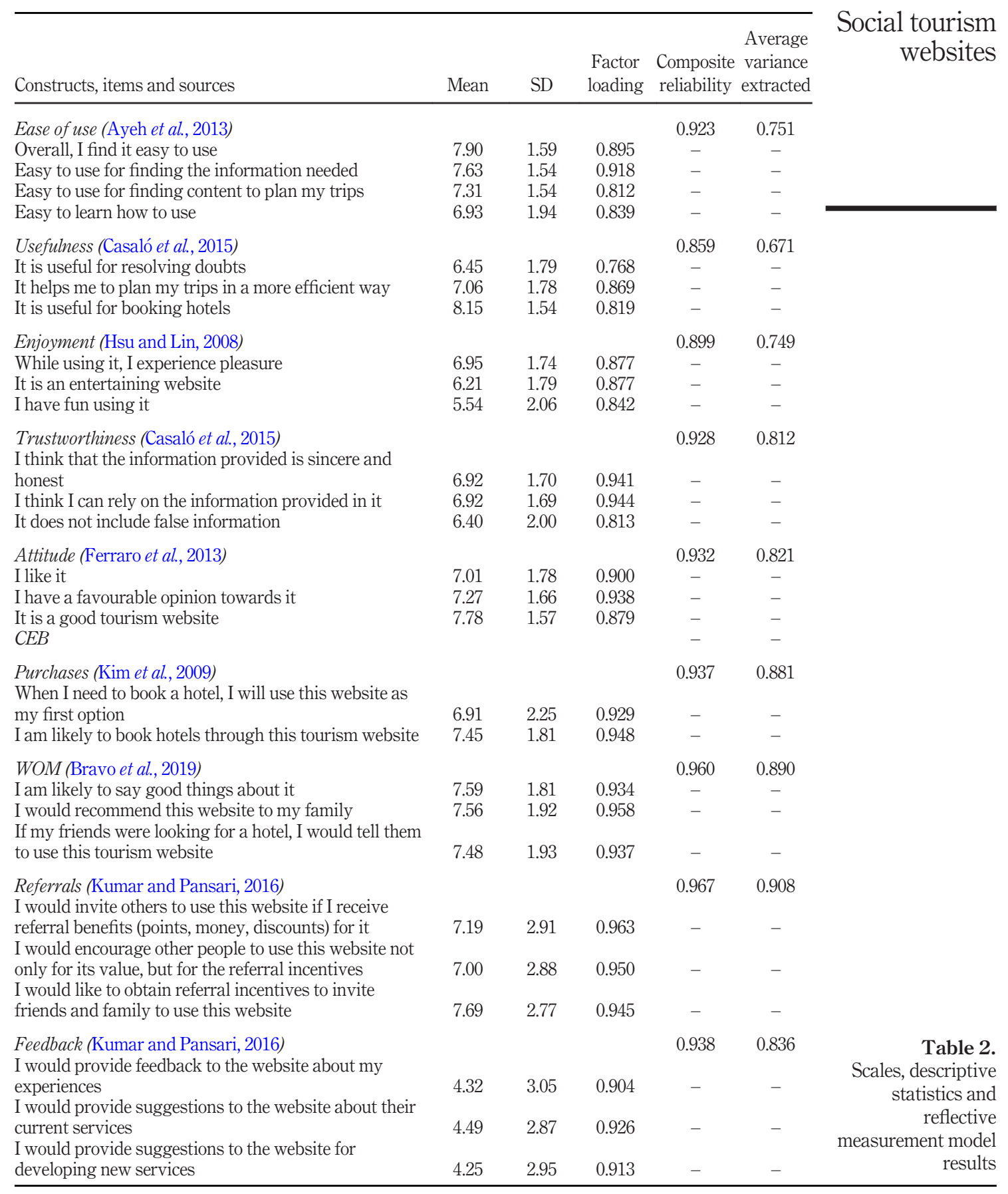


The structural model was then tested. It includes the control variables: gender, age, selfefficacy in using the internet for booking and previous use of reward systems. The path significance levels were estimated using a bootstrapping procedure with 5,000 resampling iterations. The model accounted for $66.4 \%$ of variation in attitude towards the social tourism website and $63.5 \%$ of variation in CEB. The predictive relevance of the model was assessed through the Stone-Geisser test. The results showed that the $\mathrm{Q}^{2}$ values of this test for the dependent variables were positive. Finally, as the standardised root mean square residual showed a value of 0.06, lower than the threshold of 0.08 (Hu and Bentler, 1998), we can conclude that the model has good fit.

The results of the structural model are presented in Table 5. All the hypotheses are supported. As proposed in $H 1$, the path coefficient is positive and significant, which leads us to accept the positive influence of perceived ease of use on customer attitude towards the STW $(\beta=0.297 ; t=5.852)$. The results also indicate that the customer's attitude towards the STW is determined by his/her perceptions of the usefulness of the site $(\beta=0.143$; $t=$ 2.370), supporting $H 2$. Similarly, perceptions of ease of use positively determine perceptions of usefulness $(\beta=0.577 ; t=14.086)$, which supports $H 3$. Similarly, enjoyment was found to have a significant and positive influence on customer attitude $(\beta=0.121 ; t=2.605)$ and perceived ease of use $(\beta=0.567 ; t=14.650)$, supporting $H 4$ and $H 5$. Moreover, the results showed that the perceived trustworthiness of the tourism website has a positive and significant influence on customer attitude towards it $(\beta=0.383 ; t=8.040)$ and on perceptions of the usefulness of the website ( $\beta=0.277 ; t=6.348)$, which supports $H 6$ and $H 7$. The results also showed that customer attitude towards the STW was positively related to $\mathrm{CEB}(\beta=0.583 ; t=9.700)$. Therefore, $H 8$ is supported. Finally, the mediation role of attitude was tested (Appendix).

\section{Discussion}

\subsection{Conclusions}

Recently, there has been increasing interest in STWs (Diffley and McCole, 2019), in parallel with a call for research to investigate CEB (Harrigan et al., 2017). In response to this call, this study demonstrates that TAM variables are key in explaining CEB. In line with previous research (Ayeh et al., 2013; Filieri et al., 2015), this study has demonstrated that feelings of trust towards STWs are key for developing positive attitudes and subsequent engagement. In addition, this study has shown that extrinsic motivators (ease of use and usefulness) are more important than intrinsic motivators (enjoyment) for developing positive attitudes

Table 3.

\begin{tabular}{lccccccccc}
\hline Constructs & 1 & 2 & 3 & 4 & 5 & 6 & 7 & 8 & 9 \\
\hline 1. Ease of use & 0.867 & - & - & - & - & - & - & - & - \\
2. Usefulness & 0.756 & 0.819 & - & - & - & - & - & - & - \\
3. Enjoyment & 0.568 & 0.596 & 0.865 & - & - & - & - & - & - \\
4. Trustworthiness & 0.639 & 0.647 & 0.562 & 0.901 & - & - & - & - & - \\
5. Attitude & 0.718 & 0.688 & 0.591 & 0.733 & 0.906 & - & - & - & - \\
6. Purchases & 0.592 & 0.566 & 0.476 & 0.521 & 0.637 & 0.939 & - & - & - \\
7. WOM & 0.641 & 0.590 & 0.523 & 0.579 & 0.768 & 0.739 & 0.943 & - & - \\
8. Referrals & 0.336 & 0.331 & 0.257 & 0.252 & 0.376 & 0.219 & 0.441 & 0.953 & - \\
9. Feedback & 0.230 & 0.229 & 0.301 & 0.208 & 0.274 & 0.224 & 0.291 & 0.362 & 0.914
\end{tabular}

Discriminant validity Note: Values on the diagonal are the square root of the AVE. Off-diagonal elements are the correlations results among constructs 
towards them. Although previous research has suggested that individuals may behave based on both factors (Davis et al., 1992), intrinsic factors might better explain attitude towards websites with hedonic purposes than attitude towards websites with utilitarian purposes, such as STWs, where customers seek to achieve specific goals. In addition, the results revealed that the impact of customers' perceptions on CEB is mainly mediated by customer attitude towards the STW. Thus, for users to be engaged with a specific website, it is important that they are involved with it and develop a positive attitude towards it.

\subsection{Theoretical implications}

Firstly, this study contributes to the literature, as it is the first to apply the CE theory of Kumar et al. (2010) according to the authors' knowledge, in the context of STWs to simultaneously analyse customer purchases, customer WOM, customer referrals and customer feedback. Secondly, the previous literature has not fully identified which factors might influence these behaviours. Research analysing the antecedents of CEB with STWs has focussed mainly on the characteristics of reviews, such as review valence and quantity (Sparks and Browning, 2011; Tsao et al., 2015; Chan et al., 2017). The present study advances current knowledge by providing a new perspective from the TAM (Davis, 1989), focussing on platform characteristics (ease of use, usefulness, enjoyment and trustworthiness). Thirdly, most studies on CE in tourism have been undertaken from the perspective of hotels (Xie et al., 2016; Slivar and Bayer, 2017). This study bridges this gap by developing and testing a model that analyses CEB with STWs. Finally, this study also contributes to the literature on $\mathrm{CE}$, as it provides empirical support, in a new context, for the conceptualisation of CE proposed by Kumar et al. (2010).

\subsection{Practical implications}

The results of the study might help STWs in their resource allocation strategies by identifying which factors drive better customer attitude. Customer attitude may be dependent on the perceived trustworthiness of the information provided in the STW. If users

\begin{tabular}{llcccrrr}
\hline Variable & Items & Loadings & t-value & Weights & $t$-value & VIF & \\
\hline CEB & Purchases & 0.84 & 24.02 & 0.28 & 3.84 & 2.27 & Table 4. \\
& WOM & 0.98 & 100.72 & 0.74 & 10.34 & 2.68 & Formative \\
& Referrals & 0.50 & 8.22 & 0.11 & 1.99 & 1.28 & results \\
\hline
\end{tabular}

\begin{tabular}{lcc}
\hline Hypotheses & $B$ & $t$-value \\
\hline H1: Ease of use $\rightarrow$ Attitude & 0.297 & $5.852^{* * * *}$ \\
H2: Usefulness $\rightarrow$ Attitude & 0.143 & $2.370^{* * *}$ \\
$H 3:$ Ease of use $\rightarrow$ Usefulness & 0.577 & $14.086^{* * *}$ \\
H4: Enjoyment $\rightarrow$ Attitude & 0.121 & $2.605^{* * *}$ \\
H5: Enjoyment $\rightarrow$ Ease of use & 0.567 & $14.650^{* * *}$ \\
H6: Trustworthiness $\rightarrow$ Attitude & 0.383 & $8.040^{* * *}$ \\
H7: Trustworthiness $\rightarrow$ Usefulness & 0.277 & $6.348^{* * *}$ \\
H8: Attitude $\rightarrow$ CEB & 0.583 & $9.700^{* * *}$ \\
Notes: $* * p<0.05 ; * * *<0.01$ & & Structural model \\
\end{tabular}


detect fake comments or have suspicions about the services offered, their trust in the STW will diminish and their attitude towards it will become more negative. These results are in line with the work by Filieri et al. (2015), who emphasised the importance of customer trust as a key performance indicator and proposed the use of software to promptly detect promotional or fake reviews. For instance, Booking.com sends an email to customers who book a hotel through its website, asking for their opinions. Thus, only customers who have real experiences are allowed to create content. Besides trustworthiness, ease of use may be an important lever for improving CEB with STWs. These platforms offer a lot of information, which may be overwhelming for some users. It is very important to recognise that users positively value simplicity and that tools that make a platform easier to use will be likely to enhance CEB. They should also focus on providing enjoyable experiences to their users to improve perceptions of ease of use. For instance, TripAdvisor.com has introduced gamification elements, that is, points, levels and badges, to provide its users with more enjoyable experiences. Finally, the results should alert managers to the importance of improving the usability of their STWs to reduce the time and effort required to book trips.

\subsection{Limitations and future research}

The first limitation of this study is that it uses cross-sectional data; thus, we cannot analyse $\mathrm{CEB}$ in the long term. This is an interesting avenue for future research that could be addressed through longitudinal studies. Further research might also examine the proposed relationships in other customer segments, such as business travellers. Finally, future research should examine in depth the role of customer feedback in the context of STWs. Few customers were willing to give feedback to the platform; thus, this dimension cannot be a constituent part of the CEB construct. More research should be undertaken to identify the best approach to measure CEB.

\section{References}

Ayeh, J.K., Au, N. and Law, R. (2013), "Predicting the intention to use consumer generated media for travel planning", Tourism Management, Vol. 35, pp. 132-143, doi: 10.1016/j.tourman.2012.06.010.

Bravo, R., Martínez, E. and Pina, J.M. (2019), "Effects of service experience on customer responses to a hotel chain", International Journal of Contemporary Hospitality Management, Vol. 31 No. 1, pp. 389-405, doi: 10.1108/IJCHM-09-2017-0569.

Cai, W., Richter, S. and McKenna, B. (2019), "Progress on technology use in tourism", Journal of Hospitality and Tourism Technology, Vol. 10 No. 4, pp. 651-672, doi: 10.1108/JHTT-07-2018-0068.

Carlson, J., Rahman, M., Taylor, A. and Voola, R. (2019), "Feel the VIBE: examining value-in-the-brandpage-experience and its impact on satisfaction and customer engagement behaviours in mobile social media”, Journal of Retailing and Consumer Services, Vol. 46, pp. 149-162, doi: 10.1016/j. jretconser.2017.10.002.

Casaló, L.V., Flavián, C. and Guinalíu, M. (2010), "Determinants of the intention to participate in firmhosted online travel communities and effects on consumer behavioral intentions", Tourism Management, Vol. 31 No. 6, pp. 898-911, doi: 10.1016/j.tourman.2010.04.007.

Casaló, L.V., Flavián, C. and Guinalíu, M. (2011), "Understanding the intention to follow the advice obtained in an online travel community", Computers in Human Behavior, Vol. 27 No. 2, pp. 622-633, doi: 10.1016/j.chb.2010.04.013.

Casaló, L.V., Flavián, C., Guinalíu, M. and Ekinci, Y. (2015), "Do online hotel rating schemes influence booking behaviors?", International Journal of Hospitality Management, Vol. 49, pp. 28-36, doi: 10.1016/j.ijhm.2015.05.005. 
Chan, I., Chow, C., Fong, L. and Law, R. (2017), “The effect of online reviews on hotel booking intention: the role of reader-reviewer similarity", International Journal of Hospitality Management, Vol. 66, pp. 54-65, doi: 10.1016/j.ijhm.2017.06.007.

Chen, C., Ku, E. and Yeh, C. (2019), "Increasing rates of impulsive online shopping on tourism websites", Internet Research, Vol. 29 No. 4, pp. 900-920, doi: 10.1108/INTR-03-2017-0102.

Correia-Loureiro, S.M., Godinho-Bilro, R. and Japutra, A. (2019), "The effect of consumer-generated media stimuli on emotions and consumer brand engagement", Journal of Product and Brand Management, Vol. 29 No. 3, pp. 387-408, doi: 10.1108/JPBM-11-2018-2120.

Davis, F.D. (1989), "Perceived usefulness, perceived ease of use, and user acceptance of information technology", MIS Quarterly, Vol. 13 No. 3, pp. 319-340, doi: 10.2307/249008.

Davis, F. (1993), "User acceptance of information technology: system characteristics, user perceptions and behavioral impacts", International Journal of Man-Machine Studies, Vol. 38 No. 3, pp. 475-487, doi: 10.1006/imms.1993.1022.

Davis, F.D., Bagozzi, R.P. and Warshaw, P.R. (1992), "Extrinsic and intrinsic motivation to use computers in the workplace", Journal of Applied Social Psychology, Vol. 22 No. 14, pp. 1111-1132, doi: 10.1111/j.1559-1816.1992.tb00945.x.

Di Pietro, L., Di Virgilio, F. and Pantano, E. (2012), "Social network for the choice of tourist destination: attitude and behavioural intention", Journal of Hospitality and Tourism Technology, Vol. 3 No. 1, pp. 60-76, doi: 10.1108/17579881211206543.

Diffley, S. and McCole, P. (2019), “The value of social networking sites in hotels”, Qualitative Market Research: An International Journal, Vol. 22 No. 2, pp. 114-132, doi: 10.1108/QMR-01-2017-0027.

Ferraro, R., Kirmani, A. and Matherly, T. (2013), "Look at me!, Look at me!, Conspicuous brand usage, selfbrand connection, and dilution”, Journal of Marketing Research, Vol. 50 No. 4, pp. 477-488, doi: 10.1509/ jmr.11.0342.

Filieri, R., Alguezaui, S. and McLeay, F. (2015), "Why do travelers trust TripAdvisor? Antecedents of trust towards consumer-generated media and its influence on recommendation adoption and word of mouth", Tourism Management, Vol. 51, pp. 174-185, doi: 10.1016/j.tourman.2015.05.007.

Fishbein, M. and Ajzen, I. (1975), Belief, Attitude, Intention, and Behavior, Addison-Wesley, Reading, MA.

Fornell, C. and Larcker, D. (1981), "Structural equation models with unobservable variables and measurement error: algebra and statistics", Journal of Marketing Research, Vol. 18 No. 3, pp. 382-388, doi: 10.1177\%2F002224378101800313.

Godinho-Bilro, R., Correira-Loureiro, S.M. and Ali, F. (2018), "The role of website stimuli of experience on engagement and brand advocacy", Journal of Hospitality and Tourism Technology, Vol. 9 No. 2, pp. 204-222, doi: 10.1108/JHTT-12-2017-0136.

Hair, J.F., Ringle, C.M. and Sarstedt, M. (2011), "PLS-SEM: indeed a silver bullet”, Journal of Marketing Theory and Practice, Vol. 19 No. 2, pp. 139-152, doi: 10.2753/MTP1069-6679190202.

Harrigan, P., Evers, U., Miles, M. and Daly, T. (2017), "Customer engagement with tourism social media brands", Tourism Management, Vol. 59, pp. 597-609, doi: 10.1016/j.tourman.2016.09.015.

Hinson, R., Boateng, H., Renner, A. and Basewe, J.P. (2019), "Antecedents and consequences of customer engagement on Facebook: an attachment theory perspective", Journal of Research in Interactive Marketing, Vol. 13 No. 2, pp. 204-226, doi: 10.1108/JRIM-04-2018-0059.

Hollebeek, L. (2011), "Exploring customer brand engagement: definition and themes", Journal of Strategic Marketing, Vol. 19 No. 7, pp. 555-573, doi: 10.1080/0965254X.2011.599493.

Hollebeek, L., Glynn, M. and Brodie, R. (2014), "Consumer brand engagement in social media: conceptualization, scale development and validation", Journal of Interactive Marketing, Vol. 28 No. 2, pp. 149-165, doi: 10.1016/j.intmar.2013.12.002.

Hsu, C.L. and Lin, J.C.C. (2008), “Acceptance of blog usage: the roles of technology acceptance, social influence and knowledge sharing motivation", Information and Management, Vol. 45 No. 1, pp. 65-74, doi: 10.1016/j.im.2007.11.001. 
Hu, L. and Bentler, P. (1998), "Fit indices in covariance structure modeling: sensitivity to underparameterized model misspecification", Psychological Methods, Vol. 3 No. 4, pp. 424-453, doi: 10.1037/1082-989X.3.4.424.

Hu, N., Zhang, T., Gao, B. and Bose, I. (2019), "What do hotel customers complain about? Text analysis using structural topic model", Tourism Management, Vol. 72, pp. 417-426, doi: 10.1016/j. tourman.2019.01.002.

Hussein, R. and Hassan, S. (2017), "Customer engagement on social media: how to enhance continuation of use”, Online Information Review, Vol. 41 No. 7, pp. 1006-1028, doi: 10.1108/OIR-02-2016-0047.

Itani, O., Haddad, R. and Kalra, A. (2020), "Exploring the role of extrovert-introvert customers' personality prototype as a driver of customer engagement: does relationship duration matter?", Journal of Retailing and Consumer Services, Vol. 53, doi: 10.1016/j.jretconser.2019.101980.

Kim, H., Kim, T. and Shin, S. (2009), "Modeling roles of subjective norms and eTrust in customers' acceptance of airline B2C eCommerce websites", Tourism Management, Vol. 30 No. 2, pp. 266-277, doi: 10.1016/j.tourman.2008.07.001.

Kim, S., Kandampully, J. and Bilgihan, A. (2018), "The influence of eWOM communications: an application of online social network framework", Computers in Human Behavior, Vol. 80 No. 9 , pp. 243-254, doi: 10.1016/j.chb.2017.11.015.

Kock, N. (2015), "Common method bias in PLS-SEM: a full collinearity assessment approach", International Journal of e-Collaboration, Vol. 11 No. 4, pp. 1-10, doi: 10.4018/ijec.2015100101.

Kumar, V. and Pansari, A. (2016), “Competitive advantage through engagement”, Journal of Marketing Research, Vol. 53 No. 4, pp. 497-514, doi: 10.1509/jmr.15.0044.

Kumar, V., Rajan, B., Gupta, S. and Pozza, I. (2019), "Customer engagement in service”, Journal of the Academy of Marketing Science, Vol. 47 No. 1, pp. 138-160, doi: 10.1007/s11747-017-0565-2.

Kumar, V., Aksoy, L., Donkers, B., Venkatesan, R., Wiesel, T. and Tillmanns, S. (2010), "Undervalued or overvalued customers: capturing total customer engagement value", Journal of Service Research, Vol. 13 No. 3, pp. 297-310, doi: 10.1177/1094670510375602.

Lalicic, L. and Weismayer, C. (2018), "A model of tourists' loyalty: the case of airbnb”, Journal of Hospitality and Tourism Technology, Vol. 9 No. 1, pp. 80-93, doi: 10.1108/JHTT-02-2017-0020.

Lavidge, R.J. and Steiner, G.A. (1961), “A model for predictive measurements of advertising effectiveness”, Journal of Marketing, Vol. 25 No. 6, pp. 59-62, doi: 10.2307/1248516.

Mkumbo, P.J. Ukpabi, D.C. and Karjaluoto, H. (2020), "Adapting and validating scale of customer engagement in online travel communities", European Journal of Tourism Research, Vol. 25, pp. 1-33. http://ejtr.vumk.eu/index.php/volume25/741-v25rp2501

Moro, S. and Rita, P. (2018), "Brand strategies in social media in hospitality and tourism", International Journal of Contemporary Hospitality Management, Vol. 30 No. 1, pp. 343-364, doi: 10.1108/ IJCHM-07-2016-0340.

Nunnally, A. and Bernstein, I. (1994), Psychometric Theory, McGraw-Hill. New York, NY.

Oliveira, B. and Casais, B. (2019), "The importance of user-generated photos in restaurant selection", Journal of Hospitality and Tourism Technology, Vol. 10 No. 1, pp. 2-14, doi: 10.1108/JHTT-112017-0130.

Pansari, A. and Kumar, V. (2017), "Customer engagement: the construct, antecedents and consequences", Journal of the Academy of Marketing Science, Vol. 45 No. 3, pp. 294-311, doi: 10.1007/s11747-016-0485-6.

Pourfakhimi, S., Duncan, T. and Coetzee, W. (2019), “A critique of the progress of eTourism technology acceptance research: time for a hike?", Journal of Hospitality and Tourism Technology, pp. 689-746, doi: 10.1108/JHTT-08-2018-0077.

Reinartz, W., Haenlein, M. and Henseler, J. (2009), "An empirical comparison of the efficacy of covariance-based and variance-based SEM", International Journal of Research in Marketing, Vol. 26 No. 4, pp. 332-344, doi: 10.1016/j.ijresmar.2009.08.001. 
Ringle, C., Wende, S. and Becker, J. (2015), SmartPLS 3, SmartPLS, Bönningstedt.

Ruiz-Mafe, C., Bigne-Alcañiz, E., Sanz-Blas, S. and Tronch, J. (2018), "Does social climate influence positive eWOM?”, Brq Business Research Quarterly, Vol. 21 No. 1, pp. 26-38, doi: 10.1016/j. brq.2017.12.001.

Samala, N., ; Singh, S., ; Nukhu, R. and Khetarpal, M. (2019), "Investigating the role of participation and customer-engagement with tourism brands (CETB) on social media", Academy of Marketing Studies Journal, Vol. 23, pp. 1-16.

Slivar, I. and Bayer, R. (2017), "Online referrals categorization and performance of the hospitality industry: the case of international hotel brands in Europe", Business and Economics Research Journal, Vol. 8 No. 4, pp. 835-847, doi: 10.20409/berj.2017.86.

Sparks, B. and Browning, V. (2011), "The impact of online reviews on hotel booking intentions and perception of trust", Tourism Management, Vol. 32 No. 6, pp. 1310-1323, doi: 10.1016/j. tourman.2010.12.011.

Tsao, W., Hsieh, M., Shih, L. and Lin, T. (2015), “Compliance with eWOM: the influence of hotel reviews on booking intention from the perspective of consumer conformity", International Journal of Hospitality Management, Vol. 46, pp. 99-111, doi: 10.1016/j.ijhm.2015.01.008.

Venkatesh, V. (2000), "Determinants of perceived ease of use: integrating control, intrinsic motivation, and emotion into the technology acceptance model", Information Systems Research, Vol. 11 No. 4, pp. 342-365, doi: 10.1287/isre.11.4.342.11872.

Verhoef, P., Reinartz, W. and Krafft, M. (2010), "Customer engagement as a new perspective in customer management", Journal of Service Research, Vol. 13 No. 3, pp. 247-252, doi: 10.1177/ 1094670510375461.

Xie, K.L., Zhang, Z., Zhang, Z., Singh, A. and Lee, S.K. (2016), "Effects of managerial response on consumer eWOM and hotel performance: evidence from TripAdvisor", International Journal of Contemporary Hospitality Management, Vol. 28 No. 9, pp. 2013-2034, doi: 10.1108/IJCHM-062015-0290.

Zhang, H., Wang, P.J.J. and Chen, X. (2017), "A novel decision support model for satisfactory restaurants utilizing social information: a case study of TripAdvisor.com", Tourism Management, Vol. 59, pp. 281-297, doi: 10.1016/j.tourman.2016.08.010. 


\begin{tabular}{lccccl}
\hline & \multicolumn{2}{c}{ Direct effects } & \multicolumn{2}{c}{ Indirect effects } & \\
Relations & $\beta$ & $t$-value & $\beta$ & $t$-value & Mediation \\
\hline Ease of use $\rightarrow$ CEB & 0.178 & $2.781^{* *}$ & 0.173 & $5.075^{* * *}$ & Partial \\
Usefulness $\rightarrow$ CEB & 0.067 & 0.973 & 0.083 & $2.263^{* *}$ & Full \\
Enjoyment $\rightarrow$ CEB & 0.075 & 1.598 & 0.071 & $2.498^{* *}$ & Full \\
Trustworthiness $\rightarrow$ CEB & -0.032 & 0.543 & 0.223 & $6.070^{* * *}$ & Full \\
Note: $* * p<0.05 ; * * * p<0.01$ & & & & & \\
\end{tabular}

\section{About the authors}

Rafael Bravo is Senior Lecturer at Universidad de Zaragoza. He holds a PhD since 2006, and his main research interest is focussed on consumer research and brand management. He has participated in different research projects, and nowadays, he is deepening on the study of consumer engagement in services. He has published chapters in books, working papers and conference proceedings, and he is a frequent reviewer in many journals and chair in conferences. His work has been published in journals such as Journal of Business Research, Service Industries Journal and Journal of Business Ethics. Rafael Bravo is the corresponding author and can be contacted at: rbravo@unizar.es

Sara Catalán is Assistant Professor at Universidad de Zaragoza. She received her $\mathrm{PhD}$ in Economics and Business Administration from the University of Zaragoza. Her research interests include gamification strategies and consumer behaviour. Her work has been published in journals such as Computers and Education, British Journal of Educational Technology and Studies in Higher Education. She is a member of the research group Generés recognised by the Government of Aragon.

José M. Pina holds the position of Senior Lecturer at the Department of Marketing in the University of Zaragoza (Spain), where he obtained his $\mathrm{PhD}$ in 2006. He has co-authored numerous journals articles, conference proceedings and book contributions on different branding topics such as brand extensions, brand alliances, brand image, brand equity and customer engagement. His main publications can be found in these journals: Corporate Social Responsibility and Environmental Management, European Journal of Marketing, Journal of Business Ethics, Journal of Business Research, Online Information Review and Service Industries Journal.

For instructions on how to order reprints of this article, please visit our website: 